\title{
The Predictive Role of New Markers in Early Diagnosis of Acute Kidney Injury in Patients with Acute Pancreatitis
}

\author{
Ferdi Karagözi ${ }^{*}$, Dede Şit ${ }^{2}$, Ayşegül Kırankaya ${ }^{3}$, Yasemin Aker Karagöz ${ }^{4}$, Arif Savaş ${ }^{1}$, \\ Yıldız İpek1, Bennur Esen Atay5, Ahmet Engin Atay' \\ ${ }^{1}$ Clinic of İnternal Medicine, Bağcllar Training and Research Hospital, İstanbul, Turkey \\ ${ }^{2}$ Clinic of Nephrology, Umraniye Training and Research Hospital, İstanbul, Turkey \\ ${ }^{3}$ Clinic of Biochemistry, Bağcllar Training and Research Hospital, İstanbul, Turkey \\ ${ }^{4}$ Clinic of Family Medicine, Bağcılar Training and Research Hospital, İstanbul, Turkey \\ ${ }^{5}$ Clinic of Nephrology, Bağcılar Training and Research Hospital, İstanbul, Turkey \\ Email: ^ferdikaragozz@gmail.com
}

How to cite this paper: Karagöz, F., Şit, D., Kırankaya, A., Aker Karagöz, Y., Savaş, A., İpek, Y., Esen Atay, B. and Atay, A.E. (2020) The Predictive Role of New Markers in Early Diagnosis of Acute Kidney Injury in Patients with Acute Pancreatitis. Open Journal of Nephrology, 10, 254-263. https://doi.org/10.4236/ojneph.2020.103025

Received: July 3, 2020

Accepted: September 5, 2020

Published: September 8, 2020

Copyright $\odot 2020$ by author(s) and Scientific Research Publishing Inc. This work is licensed under the Creative Commons Attribution International License (CC BY 4.0).

http://creativecommons.org/licenses/by/4.0/

\section{(c) (i) Open Access}

\begin{abstract}
Objective: Acute Kidney Injury (AKI) is a serious early complication that significantly increases the mortality rate in patients with acute pancreatitis (AP). AKI can improve with an early diagnosis and appropriate treatment protocols. We aimed to evaluate the role of IL-6, IL-18, NGAL, IL- $1 \beta$, TNF- $\alpha$, Cys-C and KIM-1 in serum and IL-18 in urine in the early detection of AKI in patients with AP. Materials and Methods: Fifty-six patients, who were diagnosed with AP and underwent standard treatment, between July 2011 and December 2013, were included in the study. Patients were sampled for markers at admission and discharge, or when the patients died. Patients were grouped by presence or absence of AKI. Results: The mean age of the cases was $56.41 \pm 20.23$ (17 - 91), of which $21(37.5 \%)$ of the cases were male and 35 (62.5\%) were female. AKI was detected in 13 (23.2\%) patients. The Cys-C level was significantly higher in AKI patients (at hospitalization $\mathrm{p}<0.01$ ). Cys-C levels at hospitalization were significantly higher than discharge levels $(\mathrm{p}<0.05)$. Serum KIM-1 level of patients with AKI was higher than the patients without AKI during admission $(\mathrm{p}<0.05)$. There was a positive correlation between serum KIM-1 and creatinine, but a negative correation between GFR and spot urine amylase/creatinine ratio during AKI patients' admission (respectively; $\mathrm{p}<0.05, \mathrm{p}<0.05, \mathrm{p}<0.05$ ). Conclusion: In this study, Cys-C and KIM-1 proved to be statistically significant to predict AKI in patients with AP. However further studies are required to support these conclusions.
\end{abstract}




\section{Keywords}

Acute Pancreatitis, AKI, Cystatin-C, KIM-1

\section{Introduction}

Acute pancreatitis (AP) is a frequent clinical table with high morbidity and mortality rates, and can result in multiple organ dysfunction including acute kidney injury (AKI) [1] [2]. Acute pancreatitis-related mortality is usually due to systemic inflammatory response syndrome (SIRS) and organ failure in the first two weeks, sepsis and complications afterwards and varies between $12 \%-47 \%$ according to clinical severity [3] [4]. Mortality rates are related to the AKI stage [5] [6] [7] [8] [9]. Early diagnosis and treatment of AKI are most important in preventing morbidity and mortality. The diagnosis of AKI is usually based on serum creatinine ( $\mathrm{SCr}$ ) levels; however, there are some diagnostic difficulties such as the late rise of the SCr level, sex, age and nutritional status. Therefore, some biomarkers are being studied for an earlier AKI diagnosis. Interleukin (IL)-1 $\beta$, IL-6, IL-18, kidney injury molecule-1 (KIM-1), tumor necrosis factor (TNF)- $\alpha$, serum cystatin C (CYS-C), and neutrophil gelatinase-related lipocalin (NGAL) showed the importance of different biomarkers in different patient populations [10]-[18].

In this study, we evaluated the efficacy of IL- $1 \beta$, IL-6, IL-18, KIM-1, TNF- $\alpha$, Cys-C, NGAL in serum and IL-18 in urine biomarkers in the early diagnosis of AKI in patients with AP.

\section{Material and Method}

\subsection{Patients}

Fifty-six patients who were diagnosed with acute pancreatitis according to diagnostic criteria for acute pancreatitis in Practice Guidelines for Acute Pancreatitis in İnternal Medicine Clinic of Bağcılar Training and Research Hospital were included in this study [19]. Among these patients, those with chronic kidney diseases, those on a program of chronic hemodialysis or peritoneal dialysis, those with acute inflammation other than AP and patients refusing treatment for various reasons or refusing to participate in the study were excluded.

The study was approved by the Bağcllar Training and Research Hospital Non-Invasive committee and was conducted between July 2011 and December 2013. Informed consent was taken from the patients. Helsinki Declaration principles were provided. The level of discharge SCr was accepted as the baseline level. The difference between admission SCr level and discharge level was evaluated according to Kidney Disease Improving Global Outcomes (KDIGO) criteria and AKI was diagnosed. According to the KDIGO criteria, AKI was defined as at least $50 \%$ increase in serum creatinine level within seven days or as an increase of $0.3 \mathrm{mg} / \mathrm{dL}$ (26.5 micromoles/L) or more within two days or as a urine 
output $<0.5 \mathrm{~mL} / \mathrm{kg} / \mathrm{h}$ for at least six or twelve hours or $<0.3 \mathrm{ml} / \mathrm{kg} / \mathrm{h}$ for twenty-four hours [20]. It was confirmed that renal failure was intrinsic by parameters such as imaging methods, biochemical analyses, fractionated sodium excretion $\left(\mathrm{FE}_{\mathrm{NA}}\right)$ and renal failure index. Blood and urine samples for IL-18, high sensitive C reactive protein (hs-CRP), Cys-C, IL-6, IL- $1 \beta$, TNF- $\alpha$, KIM- 1 , NGAL, routine biochemistry, urine and complete blood count tests for AKI and AP were taken at admission and discharge from all patients. Patients were grouped by presence or absence of AKI.

\subsection{Specimen}

Blood samples were taken in gel biochemistry tubes, centrifuged and separated into serum. Serum and urine samples were stored at $-20^{\circ} \mathrm{C}$ until the study day. Cys-C, hs-CRP, IL-1 $\beta$, IL-6, IL-18, KIM-1, NGAL, TNF- $\alpha$ were studied in these samples. DRG Diagnostics (Marburg, Germany) brand immunometric ELISA kits were used for serum hs-CRP measurements, E-bioscience (San Diego, United States) for IL-18, Aviscera Bioscience (Santa Clara, United States) for KIM-1, NGAL and Cys-C, Assaypro for IL-1 $\beta$, TNF- $\alpha$ and IL-6. Bio-Tek (Winooski, United States) ELX800 ELISA reader and Bio-Tek ELX50 washer were used for the study.

\subsection{Statistical Analysis}

Statistical Package for Social Sciences (SPSS) for Windows 15.0 program was used for analyzing results statistically. Kolmogorov-Smirnov test was used for normal distribution suitability of parameters. Student $t$ test for normal distribution of the parameters between two groups of comparisons, Mann Whitney $U$ test for comparison between two groups of parameters with no normal distribution for descriptive statistical methods (Mean, Standard deviation) as well as the comparison of quantitative data were used while evaluating the data. Paired sample $t$ test was used for in-group comparisons of normal distribution parameters, Wilcoxon sign test for in-group comparisons of parameters with no normal distribution. Fisher's Exact Chi-Square test was used for the comparison of qualitative data. Logistic regression analysis was used to evaluate how one or more independent variables affect the dependent variable separately and together.

Significance was evaluated at $\mathrm{p}<0.05$.

\section{Results}

The mean age of the cases was $56.41 \pm 20.23$ (17 - 91), of which $21(37.5 \%)$ of the cases were male and 35 (62.5\%) were female. Mean age was significantly higher in the AKI group than in non-AKI group $(\mathrm{p}<0.05)$. AKI was developed in 13 $(23.2 \%)$ cases. Renal replacement therapy was needed in only one patient. We detected that AKI was at stage 1 in five patients according to KDIGO criteria, stage 2 in three patients and stage 3 in five patients.

Serum parameters related with AP and AKI according to renal failure are shown in Table 1. 
In the present study, patients diagnosed with $\mathrm{AKI}$ presented $\mathrm{FE}_{\mathrm{Na}}$ and kidney failure index values above $1 \%$ and no signs of obstruction on the ultrasound studies suggesting AKI to be caused by intrinsic renal damage in all cases.

The Cys-C levels at admission and discharge of patients with AKI were significantly higher than those without AKI (respectively; $p<0.05, p<0.01$ ). In cases with and without kidney injury, the decrease in discharge Cys-C levels relative to the admission Cys-C levels was significant (respectively; $\mathrm{p}<0.05, \mathrm{p}<0.05$ ). The serum NGAL and IL-6 levels at the discharge of patients with AKI were significantly higher than without AKI (respectively; $\mathrm{p}<0.05, \mathrm{p}<0.05$ ). Although there was no significant change in the levels of serum IL- 6 and TNF- $\alpha$ of patients with AKI, there was significant, respectively, decrease and increase in patients without AKI (respectively; $\mathrm{p}<0.01, \mathrm{p}<0.01$ ). It was determined that there was significant difference between the serum KIM-1 levels at admission of patients with and without AKI (respectively; $\mathrm{p}<0.05, \mathrm{p}<0.05$ ). The other results of serum and urine biomarkers are shown in Table 2.

Table 1. Evaluation of levels of serum parameters of patients at Admission and Discharge according to presence or absence of kidney injury.

\begin{tabular}{|c|c|c|c|c|}
\hline & & \multicolumn{2}{|c|}{ Acute Kidney Injury } & \multirow{3}{*}{$\mathrm{p}$} \\
\hline & & Yes & No & \\
\hline & & Mean \pm SD (Median) & Mean \pm SD (Median) & \\
\hline \multirow{3}{*}{$\begin{array}{c}\text { Amylase } \\
(\mathrm{U} / \mathrm{L})\end{array}$} & ${ }^{1} \mathrm{Adm}$ & $1117 \pm 842.72(819.00)$ & $1347.63 \pm 1653.95(954.00)$ & 0.930 \\
\hline & ${ }^{1}$ Disc & $121.15 \pm 77.58(78.00)$ & $98.37 \pm 62.86(82.00)$ & 0.229 \\
\hline & ${ }^{2} \mathrm{p}$ & $0.001^{* *}$ & $0.001^{* *}$ & \\
\hline \multirow{3}{*}{$\begin{array}{l}\text { Lipase } \\
(\mathrm{U} / \mathrm{L})\end{array}$} & ${ }^{1} \mathrm{Adm}$ & $2190.62 \pm 1750.25(1984.00)$ & $1648.63 \pm 1074.74(1382.00)$ & 0.290 \\
\hline & ${ }^{1}$ Disc & $109.50 \pm 83.54(94.00)$ & $88.19 \pm 67.39(63.00)$ & 0.438 \\
\hline & ${ }^{2} \mathrm{p}$ & $0.001^{* *}$ & $0.001^{* *}$ & \\
\hline \multirow{3}{*}{$\begin{array}{c}\text { Urea } \\
\text { (mg/dl) }\end{array}$} & ${ }^{1} \mathrm{Adm}$ & $179.43 \pm 151.65(142.00)$ & $30.54 \pm 9.28(30.00)$ & $0.001^{* *}$ \\
\hline & ${ }^{1}$ Disc & $55.24 \pm 34.34(53.50)$ & $27.95 \pm 32.62(23.50)$ & $0.002^{* *}$ \\
\hline & ${ }^{2} \mathrm{p}$ & $0.005^{\star *}$ & $0.001^{\star *}$ & \\
\hline \multirow{3}{*}{$\begin{array}{c}\text { Creatinine } \\
(\mathrm{mg} / \mathrm{dl})\end{array}$} & ${ }^{1} \mathrm{Adm}$ & $5.10 \pm 5.16(3.36)$ & $0.8 \pm 0.21(0.75)$ & $0.001^{* *}$ \\
\hline & ${ }^{1}$ Disc & $1.74 \pm 1.56(1.19)$ & $0.74 \pm 0.23(0.73)$ & $0.002^{* *}$ \\
\hline & ${ }^{2} \mathrm{p}$ & $0.007^{* *}$ & $0.001^{\star *}$ & \\
\hline \multirow{3}{*}{$\begin{array}{l}\text { Sodium } \\
(\mathrm{mmol} / \mathrm{L})\end{array}$} & ${ }^{3} \mathrm{Adm}$ & $139.69 \pm 10.26$ & $139.26 \pm 5.00$ & 0.834 \\
\hline & ${ }^{3}$ Disc & $138.92 \pm 3.23$ & $139.86 \pm 3.86$ & 0.430 \\
\hline & ${ }^{4} \mathrm{p}$ & 0.816 & 0.442 & \\
\hline \multirow{3}{*}{$\begin{array}{l}\text { Potassium } \\
(\mathrm{mmol} / \mathrm{L})\end{array}$} & ${ }^{1} \mathrm{Adm}$ & $4.81 \pm 1.40(4.48)$ & $4.97 \pm 5.19(4.10)$ & 0.137 \\
\hline & ${ }^{1}$ Disc & $4.09 \pm 0.74(3.90)$ & $4.14 \pm 0.77(4.10)$ & 0.907 \\
\hline & ${ }^{2} \mathrm{p}$ & $0.049^{*}$ & 0.456 & \\
\hline
\end{tabular}

${ }^{1}$ Mann Whitney U Test, ${ }^{2}$ Wilcoxon Sign Test, ${ }^{3}$ Student $t$ test, ${ }^{4}$ Paired Sample $t$ test ${ }^{* *} \mathrm{p}<0.01$ Adm: Admission Disc: Discharge. 
Table 2. Evaluation of levels of serum and urine markers of patients at Admission and Discharge according to presence or absence of kidney injury.

\begin{tabular}{|c|c|c|c|c|}
\hline \multirow{3}{*}{ Markers } & & \multicolumn{2}{|c|}{ Acute Kidney Injury } & \multirow{3}{*}{$\mathrm{p}$} \\
\hline & & Yes & No & \\
\hline & & Mean \pm SD (Median) & Mean \pm SD (Median) & \\
\hline \multirow{3}{*}{${ }^{+}$Cys-C (ng/ml) } & ${ }^{1} \mathrm{Adm}$ & $2522.15 \pm 1224.41(2581.00)$ & $1264.23 \pm 600.21$ & $0.001^{* *}$ \\
\hline & ${ }^{1}$ Disc & $1837.46 \pm 1059.69(1154.00)$ & $1064.88 \pm 455.42(960.00)$ & $0.034^{*}$ \\
\hline & ${ }^{2} \mathrm{p}$ & $0.023^{*}$ & $0.034^{*}$ & \\
\hline \multirow{3}{*}{${ }^{+} \mathrm{NGAL}(\mathrm{ng} / \mathrm{ml})$} & ${ }^{1} \mathrm{Adm}$ & $21.61 \pm 5.95(18.95)$ & $20.36 \pm 6.95(19.98)$ & 0.497 \\
\hline & ${ }^{1}$ Disc & $23.58 \pm 17.98(18.93)$ & $21.05 \pm 16.68(14.96)$ & $0.049^{*}$ \\
\hline & ${ }^{2} \mathrm{p}$ & 0.701 & 0.078 & \\
\hline \multirow{3}{*}{${ }^{+} \mathrm{KIM}-1$ (pg/ml) } & ${ }^{1} \mathrm{Adm}$ & $2951.77 \pm 3356.90(1542.00)$ & $2729.74 \pm 4779.01(1008.00)$ & $0.034^{*}$ \\
\hline & ${ }^{1}$ Disc & $1622.08 \pm 2239.57(739.00)$ & $1939.49 \pm 4405.44(448.00)$ & 0.190 \\
\hline & ${ }^{2} \mathrm{p}$ & $0.016^{*}$ & $0.001^{* *}$ & \\
\hline \multirow{3}{*}{${ }^{+} \mathrm{IL}-18(\mathrm{pg} / \mathrm{ml})$} & ${ }^{1} \mathrm{Adm}$ & $788.38 \pm 367.31(624.00)$ & $648.39 \pm 333.02(615.00)$ & 0.269 \\
\hline & ${ }^{1}$ Disc & $481.92 \pm 366.00(380.00)$ & $575.67 \pm 398.65(444.00)$ & 0.322 \\
\hline & ${ }^{2} \mathrm{p}$ & 0.055 & 0.234 & \\
\hline \multirow{3}{*}{${ }^{+} \mathrm{IL}-6(\mathrm{pg} / \mathrm{ml})$} & ${ }^{1} \mathrm{Adm}$ & $8.68 \pm 13.91(3.24)$ & $10.08 \pm 10.57(5.24)$ & 0.567 \\
\hline & ${ }^{1}$ Disc & $7.27 \pm 7.25(5.04)$ & $6.59 \pm 14.31(3.36)$ & $0.049^{*}$ \\
\hline & ${ }^{2} \mathrm{p}$ & 0.972 & $0.007^{\star *}$ & \\
\hline \multirow{3}{*}{${ }^{+} \mathrm{IL}-1 \beta(\mathrm{pg} / \mathrm{ml})$} & ${ }^{1} \mathrm{Adm}$ & $1.35 \pm 0.85(1.08)$ & $2.00 \pm 3.46(1.24)$ & 0.522 \\
\hline & ${ }^{1}$ Disc & $1.06 \pm 0.83(0.64)$ & $3.19 \pm 7.90(0.76)$ & 0.661 \\
\hline & ${ }^{2} \mathrm{p}$ & $0.023^{*}$ & $0.002^{* *}$ & \\
\hline \multirow{3}{*}{${ }^{+} \mathrm{TNF}-\alpha(\mathrm{pg} / \mathrm{ml})$} & ${ }^{1} \mathrm{Adm}$ & $26.17 \pm 46.48(4.82)$ & $43.60 \pm 181.57(6.02)$ & 0.683 \\
\hline & ${ }^{1} \mathrm{Disc}$ & $26.35 \pm 30.09(16.22)$ & $50.52 \pm 170.73(14.91)$ & 0.294 \\
\hline & ${ }^{2} \mathrm{p}$ & 0.463 & $0.001^{* *}$ & \\
\hline \multirow{3}{*}{ ths-CRP (mg/L) } & ${ }^{1} \mathrm{Adm}$ & $19.96 \pm 12.03(23.82)$ & $20.64 \pm 12.60(20.03)$ & 0.778 \\
\hline & ${ }^{1}$ Disc & $6.31 \pm 6.44(4.57)$ & $10.25 \pm 7.15(10.58)$ & 0.061 \\
\hline & ${ }^{2} \mathrm{p}$ & $0.011^{*}$ & $0.001^{* *}$ & \\
\hline \multirow{3}{*}{${ }^{++} \mathrm{IL}-18(\mathrm{pg} / \mathrm{ml})$} & ${ }^{1} \mathrm{Adm}$ & $467.77 \pm 111.99(433.00)$ & $530.09 \pm 252.93(449.00)$ & 0.294 \\
\hline & ${ }^{1}$ Disc & $469.46 \pm 223.06(448.00)$ & $548.84 \pm 216.33(495.00)$ & 0.074 \\
\hline & ${ }^{2} \mathrm{p}$ & 0.701 & 0.112 & \\
\hline
\end{tabular}

${ }^{1}$ Mann Whitney U Test, ${ }^{2}$ Wilcoxon Sign Test, ${ }^{*} \mathrm{p}<0.05{ }^{* *} \mathrm{p}<0.01 \mathrm{Adm}$ : Admission Disc: Discharge. ${ }^{+}$serum markers ${ }^{++}$urine marker.

Both spot urine and 24-hours urine protein levels at the discharge of patients with AKI were significantly higher than without AKI (respectively; $\mathrm{p}<0.05, \mathrm{p}<$ 0.05). In cases without AKI the decrease in discharge levels of spot and 24-hours urine protein relative to the admission levels of spot and 24-hours urine protein was significant (respectively; $\mathrm{p}<0.05, \mathrm{p}<0.01$ ). 
Parameters between AKI and non-AKI groups at admission were examined at logistic regression analysis. As a result of univariate logistic regression analysis, risk factors affecting AKI were examined. As a result of these analyzes, Cys-C and IL-18 variables with $\mathrm{p}$ values below 0.25 were included in the multivariate logistic regression analysis. Considering the univariate regression analysis results, an increase in Cys- $\mathrm{C}$ value by one unit increases the risk of developing AKI by 1.002 times. As a result of multivariate logistic regression analysis, only Cys-C was found to be significant and remained in the model. Logistic regression analysis results are shown in Table 3 and Table 4.

\section{Discussion}

Acute pancreatitis, especially a moderate or severe form, is associated with multisystem complications. AP can increase rates of morbidity and mortality and complicated AP can result in higher rates. Early diagnosis of AKI which is the one of most common complications of AP, has significant impact on the rates of morbidity and mortality. The incidence of AKI is $15 \%$ in patients with AP. Mortality rates can increase six folds when AKI is a complication [1] [2] [5] [6] [7] [8] [9] [21] [22]. The rise of SCr level in AKI may be delayed or affected by a number of factors including gender, age, coexisting disorder. For this reason new biomarkers are needed to diagnose AKI early. IL-6, IL-18, NGAL, IL-1 $\beta$, TNF- $\alpha$, Cys-C and KIM- 1 have been promised in many previous studies. In the present study, we aimed to examine the role of these biomarkers, and observed that Cys-C and KIM-1 were more sensitive in the diagnosis of AKI compared to IL-6, IL-18, and NGAL. Additionally, the correlation of Cys-C and KIM-1 with conventional diagnostic criteria for the disease was significant.

Although, IL-18, IL-6, IL- $1 \beta$, TNF- $\alpha$, NGAL have promising biomarkers in the diagnosis and surveillance of AKI, sepsis, malignancy, stroke and heart failure, we failed to demonstrate a significant result in our study. Liu et al., in their meta-analysis, have indicated that urine IL-18 levels are moderately predictive in determining AKI [12]. Hall et al. found significant associations between urinary NGAL, KIM-1, IL-18 levels and the progression of AKI and mortality rates in the hospital [23]. Haase et al. found no significant difference between patients with and without AKI during both intensive care unit (ICU) hospitalization and postoperative 24 hours in terms of urinary IL-18 levels [24].

Kim et al. found that plasma NGAL levels were significantly higher in patients with sepsis with AKI than in those without AKI [15]. Pickering and Endre found that an increase in the level of plasma NGAL was significant for detecting AKI in patients with both functional and structural AKI, with more significant in structural AKI [16]. Lin et al. found that APACHE III score, serum IL-18 and Cys-C levels on the first day of renal replacement therapy in patients with AKI, who were transferred to the ICU, were the independent predictors of mortality [18]. Tsigou et al. reported that NGAL, Cys-C, KIM-1, IL-18, and L-FABP were more effective for detecting AKI pior to elevation of the SCr level [25]. 
Table 3. Logistic regression-when variables are modeled individually.

\begin{tabular}{ccccccc}
\hline $\begin{array}{c}\text { Independent } \\
\text { Variables }\end{array}$ & $\beta$ & S.E. & p value & OR & \multicolumn{2}{c}{$95 \%$ Confidence Interval } \\
\hline${ }^{++}$IL-18 & -0.002 & 0.002 & 0.405 & 0.998 & 0.994 & 1.003 \\
+ Lys-C & 0.002 & 0.001 & 0.001 & 1.002 & 1.001 & 1.002 \\
${ }^{+}$NGAL & 0.028 & 0.047 & 0.556 & 1.028 & 0.938 & 1.127 \\
${ }^{+}$KIM-1 & 0.001 & 0.001 & 0.883 & 1.001 & 0.998 & 1.003 \\
${ }^{+}$IL-18 & 0.001 & 0.001 & 0.201 & 1.001 & 0.999 & 1.003 \\
${ }^{+}$IL-6 & -0.012 & 0.030 & 0.695 & 0.988 & 0.931 & 1.049 \\
${ }^{+}$IL-1 $\beta$ & -0.134 & 0.229 & 0.558 & 0.874 & 0.558 & 1.370 \\
${ }^{+}$TNF- $\alpha$ & -0.001 & 0.003 & 0.736 & 0.999 & 0.994 & 1.004 \\
${ }^{+}$hs-CRP & -0.004 & 0.026 & 0.862 & 0.996 & 0.946 & 1.047 \\
\hline
\end{tabular}

$\beta$ : Beta coefficient, S.E.: Standard error of mean, OR: Odds Ratio ${ }^{+}$serum markers, ${ }^{++}$urine marker.

Table 4. Multivariable logistic regression-when variables are modeled together.

\begin{tabular}{ccccccc}
\hline $\begin{array}{c}\text { Independent } \\
\text { Variables }\end{array}$ & $\beta$ & S.E. & p value & OR & \multicolumn{2}{c}{ \%95 Confidence Interval } \\
\hline Constant & -4.856 & 1.377 & $<0.001$ & 0.008 & - & Lower Bound \\
\hline+ Upper Bound \\
\hline${ }^{+}$Cys-C & 0.002 & 0.001 & 0.001 & 1.002 & 1.001 & 1.003 \\
+ IL-18 & 0.001 & 0.001 & 0.300 & 1.001 & 0.999 & 1.003 \\
\hline
\end{tabular}

$\beta$ : Beta coefficient, S.E.: Standard error of mean, OR: Odds Ratio ${ }^{+}$serum markers.

Cys-C is an extracellular cysteine protease inhibitor, which is filtered from the glomeruli and reabsorbed from the proximal tubules. In contrast to SCr, blood levels are not affected by factors such as age, gender, muscle mass and race [17]. Cys- $\mathrm{C}$ has been recognized as an early predictor of AKI and an independent indicator of mortality [26] [27] [28]. KIM-1 is a type-1 cell membrane protein produced in proximal tubular epithelial cells that increases in AKI, fibrosis, renal cell carcinoma, and polycystic kidney disease. Two systematic reviews have reported that KIM-1 is a novel biomarker that is effective in diagnosing AKI within 24 hours of kidney injury, especially in ischemic acute tubular necrosis [29] [30]. In critically ill patients, the use of Cys-C for the prediction of AKI was investigated after cardiac surgery, nephrotoxic drugs, and renal transplantation, and has been shown that serum Cys-C and KIM-1 may be more useful in early detection of AKI compared to IL-18, IL- $1 \beta$, IL-6, TNF- $\alpha$, NGAL and hs-CRP in patients with AP [27]. Aydogdu et al. showed that plasma and urine Cys-C were good markers for early recognition of sepsis-associated AKI. However, several studies in adults have shown that sepsis has no effect on plasma or urine levels of Cys-C [31] [32]. Despite extensive analysis, the application of KIM-1 in the early diagnosis of AKI still needs to be verified and thoroughly investigated because of the heterogeneous patient population, less clinical trial and limited different de- 
tection time in a relatively limited number of patient groups.

The present study has some potential drawbacks. First, the sample number in our study was relatively low which may affect the significance of the results. We collected samples only at admission and discharge. Serial measurement of biomarkers may provide more valuable data. We do not know baseline SCr levels; we accepted baseline serum creatinine values as acute pancreatitis was healed. As the present study has not included post discharge clinical follow-up, continued kidney function recovery may have led to lower post discharge creatinine clearance values eventually reaching the basal creatinine clearance values which were not available at the patients' admission. Therefore, in the diagnosis of AKI in patients with AP, the diagnostic value of KIM-1 and Cys-C needs to be verified with studies to be conducted with a larger sample.

\section{Conclusion}

Many urines and serum markers are being evaluated due to inadequate early detection of serum creatinine in AKI. Among these, serum NGAL and Cys-C are the most studied. In our study, Cys-C and KIM-1 appear to be helpful in the early diagnosis of AKI in patients with acute pancreatitis. However, it seems that there is a need for large-scale and long-term studies to obtain clearer data.

\section{Supporting Organizations}

In this study the Bağcrlar Training and Research Hospital working capital fund support was obtained.

\section{Conflicts of Interest}

The authors declare no conflicts of interest regarding the publication of this paper.

\section{References}

[1] Steer, M.L. (1993) Etiology and Pathophysiology of Acute Pancreatitis. In: Go, V.L.V., Dimango, E.P., Gardner, J.D., Lebenthal, E., Rober, H.A. and Scheele, G.A., Eds., The Pancreas. Biology, Pathobiology, and Disease, Raven, New York, 581-592.

[2] Greenberger, N.J. and Toskes, P.P. (2005) Acute and Chronic Pancreatitis. In: Kasper, D.L., Fauci, A.S., Longo, D.L., Braunwald, E., Hauser, S.L. and Jameson, J.L., Eds., Harrison's Principles of Internal Medicine, 16th Edition, McGraw Hill, New York, 1895-1906.

[3] Gloor, B., Müller, C.A., Womi, M., Martignoni, M.E., Uhl, W. and Büchler, M.W. (2001) Late Mortality in Patients with Severe Acute Pancreatitis. British Journal of Surgery, 88, 975-979. https://doi.org/10.1046/j.0007-1323.2001.01813.x

[4] Multinga, M., Rosenbluth, A., Tenner, S.M., Odze, R.R., Sica, G.T. and Banks, P.A. (2000) Does Mortality Occur Early or Late in Acute Pancreatitis? International Journal of Pancreatology, 28, 91-95. https://doi.org/10.1385/IJGC:28:2:091

[5] Pekmezci, S. (2002) Akut pankreatitte Yaklaşım ve Tedavi. In: Göksoy, E. and Şentürk, H., Eds., Proceedings of Symposium Series, Publication No. 28 of Cerrahpaşa Medical Faculty of İstanbul University, Continuous Medical Activities of Cerrahpaşa 
Medical Faculty of İstanbul University, İstanbul, 239-262.

[6] Zhang, X.P., Wang, L. and Zhou, Y.F. (2008) The Pathogenic Mechanism of Severe Acute Pancreatitis Complicated with Renal İnjury: A Review of Current Knowledge. Digestive Diseases and Sciences, 53, 297-306. https://doi.org/10.1007/s10620-007-9866-5

[7] Li, H., Qian, Z., Liu, Z., Liu, X., Han, X. and Kang, H. (2010) Risk Factors and Outcome of Acute Renal Failure in Patients with Severe Acute Pancreatitis. Journal of Critical Care, 25, 225-229. https://doi.org/10.1016/j.jcrc.2009.07.009

[8] Suh, S.H., Kim, C.S., Choi, J.S., Bae, E.H., Ma, S.K. and Kim, S.W. (2013) Acute Kidney İnjury in Patients with Sepsis and Septic Shock: Risk Factors and Clinical Outcomes. Yonsei Medical Journal, 54, 965-972. https://doi.org/10.3349/ymj.2013.54.4.965

[9] Fuchs, L., Lee, J., Novack, V., Baumfeld, Y., Scott, D., Celi, L., et al. (2013) Severity of Acute Kidney Injury and Two-Year Outcomes in Critically Ill Patients. Chest, 144, 856-875. https://doi.org/10.1378/chest.12-2967

[10] Waikar, S.S. and Bonventre, J.V. (2012) Acute Kidney İnjury. In: Longo, D.L., Kasper, D.L., Jameson, J.L., Fauci, A.S., Hauser, S.L. and Loscalzo, J., Eds., Harrison's Principles of Internal Medicine, 18th Edition, McGraw-Hill Medical, New York, 2293-2308.

[11] McCullough, P.A., Shaw, A.D., Haase, M., Bouchard, J., Waikar, S.S., Siew, E.D., et al. (2013) Diagnosis of Acute Kidney İnjury Using Functional and İnjury Biomarkers: Workgroup Statements from the Tenth Acute Dialysis Quality Initiative Consensus Conference. Contributions to Nephrology, 182, 13-29. https://doi.org/10.1159/000349963

[12] Liu, Y., Guo, W., Zhang, J., Xu, C., Yu, S., Mao, Z., et al. (2013) Urinary Interleukin 18 for Detection of Acute Kidney Injury: A Meta-Analysis. American Journal of Kidney Diseases, 62, 1058-1067. https://doi.org/10.1053/j.ajkd.2013.05.014

[13] Obermüller, N., Geiger, H., Weipert, C. and Urbschat, A. (2014) Current Developments in Early Diagnosis of Acute Kidney İnjury. International Urology and Nephrology, 46, 1-7. https://doi.org/10.1007/s11255-013-0448-5

[14] Martín Alonso, M.A., Santamaría, A., Saracíbar, E., Arranz, E., Garrote, J.A., Almaraz, A., et al. (2007) Cytokines and Other İmmunological Parameters as Markers of Distant Organ İnvolvement in Acute Pancreatitis. Medicina Clínica (Barc), 128, 401-406. https://doi.org/10.1157/13100335

[15] Kim, H., Hur, M., Cruz, D.N., Moon, H.W. and Yun, Y.M. (2013) Plasma Neutrophil Gelatinase-Associated Lipocalin as a Biomarker for Acute Kidney İnjury in Critically İll Patients with Suspected Sepsis. Clinical Biochemistry, 46, 1414-1418. https://doi.org/10.1016/j.clinbiochem.2013.05.069

[16] Pickering, J.W. and Endre, Z.H. (2013) The Clinical Utility of Plasma Neutrophil Gelatinase-Associated Lipocalin in Acute Kidney Injury. Blood Purif, 35, 295-302. https://doi.org/10.1159/000351542

[17] Murty, M.S., Sharma, U.K., Pandey, V.B. and Kankare, S.B. (2013) Serum Cystatin $\mathrm{C}$ as a Marker of Renal Function in Detection of Early Acute Kidney İnjury. Indian Journal of Nephrology, 23, 180-183. https://doi.org/10.4103/0971-4065.111840

[18] Lin, C.Y., Chang, C.H., Fan, P.C., Tian, Y.C., Chang, M.Y., Jenq, C.C., et al. (2013) Serum İnterleukin-18 at Commencement of Renal Replacement Therapy Predicts Short-Term Prognosis in Critically İll Patients with Acute Kidney İnjury. PLoS ONE, 8, e66028. https://doi.org/10.1371/journal.pone.0066028

[19] Banks, P.A. and Freeman, M.L. (2006) Practice Guidelines in Acute Pancreatitis. 
The American Journal of Gastroenterology, 101, 2379-2400. https://doi.org/10.1111/j.1572-0241.2006.00856.x

[20] Kellum, J.A., et al. (2012) Kidney Disease: Improving Global Outcomes (KDIGO) Acute Kidney Injury Work Group. KDIGO Clinical Practice Guideline for Acute Kidney Injury. Kidney International Supplements, 2, 1-138.

[21] Lin, H.Y., Lai, J.I., Lai, Y.C., Lin, P.C., Chang, S.C. and Tang, G.J. (2011) Acute Renal Failure in Severe Pancreatitis: A Population-Based Study. Upsala Journal of Medical Sciences, 116, 155-159. https://doi.org/10.3109/03009734.2010.547636

[22] Yaqub, M.S. and Molitoris, B.A. (2012) Akut Böbrek Hasarı. In: Lerma, E.V., Berns, J.S. and Nissenson, A.R., Eds., Nefroloji ve Hipertansiyon, Güneş Tıp Kitabevleri, Ankara, 89-98.

[23] Hall, I.E., Coca, S.G., Perazella, M.A., Eko, U.U., Luciano, R.L., Peter, P.R., et al. (2011) Risk of Poor Outcomes with Novel and Traditional Biomarkers at Clinical AKI Diagnosis. Clinical Journal of the American Society of Nephrology, 6, 2740-2749. https://doi.org/10.2215/CJN.04960511

[24] Haase, M., Bellomo, R., Story, D., Davenport, P. and Haase-Fielitz, A. (2008) Urinary İnterleukin-18 Does Not Predict Acute Kidney İnjury after Adult Cardiac Surgery: A Prospective Observational Cohort Study. Critical Care, 12, R96. https://doi.org/10.1186/cc6972

[25] Tsigou, E., Psallida, V., Demponeras, C., Boutzouka, E. and Baltopoulos, G. (2013) Role of New Biomarkers: Functional and Structural Damage. Critical Care Research and Practice, 2013, Article ID: 361078. https://doi.org/10.1155/2013/361078

[26] Nejat, M., Pickering, J.W., Walker, R.J., Westhuyzen, J., Shaw, G.M., Frampton, C.M., et al. (2010) Urinary Cystatin C İs Diagnostic of Acute Kidney İnjury and Sepsis and Predicts Mortality in the İntensive Care Unit. Critical Care, 14, R85. https://doi.org/10.1186/cc9014

[27] Aydogdu, M., Gursel, G., Sancak, B., Yeni, S., Sari, G., Tasyurek, S., et al. (2013) The Use of Plasma and Urine Neutrophil Gelatinase-Associated Lipocalin (NGAL) and Cystatin C in Early Diagnosis of Septic Acute Kidney İnjury in Critically İll Patients. Disease Markers, 34, 237-246. https://doi.org/10.1155/2013/740351

[28] Bouchon, A., Facchetti, F., Weigand, M.A. and Colonna, M. (2001) TREM-1 Amplifies İnflammation and İs a Crucial Mediator of Septic Shock. Nature, 410, 1103-1107. https://doi.org/10.1038/35074114

[29] Huang, Y. and Don-Wauchope, A.C. (2011) The Clinical Utility of Kidney Injury Molecule 1 in the Prediction, Diagnosis, and Prognosis of Acute Kidney İnjury: A Systematic Review. Inflammation \& Allergy_Drug Targets, 10, 260-271. https://doi.org/10.2174/187152811796117735

[30] Coca, S.G., Yalavarthy, R., Concato, J. and Parikh, C.R. (2008) Biomarkers for the Diagnosis and Risk Stratification of Acute Kidney İnjury: A Systematic Review. Kidney International, 73, 1008-1016. https://doi.org/10.1038/sj.ki.5002729

[31] Nejat, M., Pickering, J.W., Walker, R.J. and Endre, Z.H. (2010) Rapid Detection of Acute Kidney İnjury by Plasma Cystatin C in the İntensive Care Unit. Nephrology Dialysis Transplantation, 25, 3283-3289. https://doi.org/10.1093/ndt/gfq176

[32] Martensson, J., Martling, C.R., Oldner, A. and Bell, M. (2012) Impact of Sepsis on Levels of Plasma Cystatin C in AKI and Non-AKI Patients. Nephrology Dialysis Transplantation, 27, 576-581. https://doi.org/10.1093/ndt/gfr358 